Article

\title{
On the Economic Effects of a Res Local Industry Deployment in Morocco: A Case of Study Defining Scenarios from a Survey to Stakeholders
}

\author{
Ramon Mahia and Rafael de Arce *(D) \\ Department of Applied Economics (Econometrics), University Autonomous of Madrid, 28049 Madrid, Spain; \\ ramon.mahia@uam.es \\ * Correspondence: rafael.dearce@uam.es
}

Received: 14 July 2020; Accepted: 19 August 2020; Published: 21 August 2020

check for updates

\begin{abstract}
The aim of this article is to simulate the economic impact on Gross Domestic Product (GDP) and employment of renewable energy sources investment in Morocco over the next 40 years. In this sense, several potential scenarios of energy component evolution have been used based on the results of a specific survey to sector stakeholders. We obtain accurate results, avoiding speculative/theoretical assumptions in terms of scenario design. As usual in the sector, a Dynamic Input-Output Model (DI-O) is used to estimate the direct and indirect effects of such a large investment and, avoiding the criticism of this type of model in the context of long-term simulations, the alternative of de Arce et al. (2012) is used. In this framework, substantial results derive from the three scenarios considered: the increase in Moroccan GDP as a result of this investment could be around 1.2-1.7 points and, on average, 42,000 new jobs could be created.
\end{abstract}

Keywords: RES; investments; economic impact; CSP and component dependency

\section{Introduction}

In this article, we estimate the economic effects on the value added and employment of renewable energy source (RES) investments in Morocco in the next 40 years, defining several scenarios about the level of local manufacturing of windmills, Concentrated Solar Power (CSP) and Photovoltaic (PV) components to be installed, maintained and operated during this period. In order to define these scenarios, we use the results from an expert face-to-face survey conducted in May 2014. For the estimation of the economic effects, we use a Dynamic Input-Output Model (DI-O) in the same way that de Arce et al. did [1].

Our intention in this article is not to offer details about the econometric model used to simulate the different scenarios, but to clearly specify the stages of this simulation and to shed light on a more coherent result, considering the main actors of the market: firms, governments and international institutions.

The main contribution of this research is to clarify the perspectives of RES investment in Morocco through a more realistic approach, combining this information with a well-tested (and improved) academic model such as the DI-O [1,2].

Our main concern in the more robust design of local manufacturing simulation scenarios is focused on the CSP industry. In the case of the other technologies contained in our estimates (wind and photovoltaic), we assume that the mature level of these industries will take a similar course on local manufacturing in Morocco in the coming years. Nevertheless, we open the door to further research on the evolution of the Moroccan industry in these technologies.

Through this research, we have found valuable effects of RES investments on Morocco's Gross Domestic Product (GDP) and employment over the next 40 years. The effects of the implementation 
of RES technologies in electrical generation in this country could represent 1.27-1.7 points of Gross Domestic Product (GDP) per decade, depending on the simulation scenario chosen. In the context of 'minor changes', the employment could increase by up to 42,000 new jobs in a decennium (including direct and indirect employees).

The search for clean alternatives to produce electricity is a fact that does not require discussion. The environmental implications of production using traditional sources produce an accelerated deterioration of the healthiness of the air that affects, in the short, medium and long term, the quality of life on the planet in all spheres in which it can be contemplated. In this sense, the economic analysis of the different existing technical alternatives becomes a key factor when carrying out investments of the scope and amount that require the construction of power plants based on renewable energy sources, in line with the 2030 agenda and the Sustainable Development Goals (SDG) in Africa (as cited by Simionescu et al. [3]. RES deployment means: (i) securing the energy supply and costs, (ii) ensuring lower energy costs and international dependency, (iii) protecting the environment, and (iv) improving energy networks.

Quoting Adenle [4], "The rising energy demand in Africa as a result of the growing population represents one of the most significant challenges to sustainable economic growth. In light of increasing energy demand, rising energy prices and the need to reinforce necessary measures against global warming, renewable energy sources remain part of the global solution and have been widely exploited around the world recently".

RES based on solar energy find a set of technical conditions extraordinarily suitable in very specific strips of the planet, where the Density of Normal Irradiation (DNI) far exceeds that of other areas of the planet, coupled with the fact that the conditions of wind, humidity and height, etc., must be considered optimal for the development of concentrated solar plants (CSP). Morocco is one of the countries that meets these conditions.

In the case of Morocco, the country's commitment to the creation of CSPs fulfils a double strategy: on the one hand, it contributes to the clean and efficient exploitation of a resource that has come to be called "Green Gold" (by analogy with the "Black Gold" that oil represented in countries in the Middle East). The possibilities of converting the Moroccan economy into an economy based on RES allows for clear progress towards a sustainable future. On the other hand, its proximity to the European Union makes the country an exceptional candidate to contribute to the deficit of clean electricity in the Union, where the commitment to sustainable energy production (EU directive 2009/28/EC on the promotion of the use of energy from renewable sources) can be fulfilled both within its own borders, and by importing it from countries that produce clean energy. Thus, Morocco also has an enormous window of opportunity open to it as an energy supplier to countries on the European continent.

Additionally, the extension of the territory that is potentially employable for the construction of solar plants makes Morocco an ideal place to take advantage of this opportunity. Although similar circumstances exist in Algeria, the country's level of development in natural gas exploitation means that, for the time being, this has not been its priority [4,5].

Within this framework, an economic analysis of the potential of these solar plants becomes fundamental. Although there have been some studies on this subject, the specific and comparative case of Morocco (looking at CSP as an alternative to wind and PV) has been scarcely analysed. Adenle [6] reviews the existing literature on the subject and only finds a dozen articles referring to the particular case of Morocco, among which Arce et al. [1], MENA [7], Medina et al. [8] and Adenle et al. [9] stand out.

They all highlight the need to approach the analysis from a comparative point of view (with other alternative RES) and take into account the difficult socio-economic framework that conditions investment in the area, based on the surveys of experts and stakeholders, to determine the key variables that could speed up or slow down the process, as is done in this article using the information obtained from the survey by Mahia et al. [2]. Jenniches [10] investigates the importance of analysis at a smaller geographical scale- the regional scale-where the size of the territory allows for the discovery of 
more significant impacts derived from investment in RES. Unfortunately, this author regrets the small number of analyses of this type and, frequently, the existence of these analyses only in the vernacular language of the area means that their effects have scarcely been disseminated. Dees and Auktor [11] carried out a comparative analysis in several countries in the MENA area with uncertain results about its economic effect due to the enormous investment needed to start production and the still high relative cost of production of this type of energy, compared only in economic terms with other fossil sources.

Very recently, Kiefer and del Rio [12] undertook an extensive review of the existing literature on drivers and barriers to investment in CSP in the European Union, aimed at both experts and investors. The authors point out that, for the experts, support for deployment, the improvement of the regulatory framework and attention to complementarity with PV will be the factors that will drive deployment in the coming years. For the most critical investors, issues with grid connectivity, administrative processes and technological development are identified as major barriers.

This article is organized as follows. After this introduction, the methodology and phases of our research are briefly exposed. In Section 3, the baseline of electricity demand and power installation in Morocco for the next 40 years is set up and the investment necessities are estimated. In Section 4, we design the import component scenarios based on the results of our survey. In Section 5, the macroeconomic results of the simulation (in terms of GDP and employment) are presented. Finally, in Section 6, we offer our conclusions.

\section{Methodology}

Input-Output models are commonly used in the framework of the economic impact of a large investment in a country and, in particular, they become the most popular instrument for analysing the socio-economic effects in the field of energy investment plans [1,13-19]. It is also common to use panel data models to compare the effect of GDP growth on RES deployment (see [3]), but such approaches are not in line with our objective to establish the economic effects of investing in RES on GDP growth and job creation.

Following the same methodology used in [1] for estimating the impact on GDP and the employment of a future CSP industry in Morocco, we have followed the next steps in this research:

- Planning of the future electrical demand in Morocco using international sources (IEA, MASEN, etc).

- Setting up of the Electric Production Mix of Morocco for the next few years (using information from MASEN and the Ministry of Energy and mines of Morocco and University of Rabat FEMISE team).

- Definition of the requirements of installed energy sources by technology in order to supply the domestic projected demand of electricity.

- Using the international standards of investment cost for CSP technologies, determination of the total amount of funds to install this electrical capacity in the country-for defining the business plan of each technology, we have used the information available in $[1,17]$ (see Tables A1-A3 in the Appendix A).

- Assignment of each component to its respective economic sector in the I-O of Morocco.

- Computation of the domestic part of the total investment as the Direct Production Effect on the involved sectors (see Table A4 in the Appendix A).

- Estimation of the Total Production effect (direct plus indirect) through the dynamic Leontief Matrix.

- Derivation of the number of total employees and value-added effects from the proper coefficients of the I-O table and productivity dynamic rates.

- In a second round, the determination of the new impact on domestic demand produced by new consumption yield from the employees in the first round (estimation of Induced Demand Effect).

A certain weakness of this procedure comes from the intrinsic definition of the I-O structure: it is a fixed picture of the economy in a certain period of time and thus it is not easy to argue that this structure will be the same in a long forecasting horizon. To solve this problem-and in the framework of a simulation of more than 40 years such as the one we are managing - the dynamic evolution of the 
I-O structure is inevitable. Therefore, we decided to use the RAS technique to evolve the Moroccan technical coefficient matrix through a more developed economy, the French one. [1,20-22]

In our model, we draw a progressive evolution of the industrial structure of Morocco, changing the links between sectors to resemble the way that they are connected in a more developed economy. This progressive convergence of the Moroccan I-O marginal does not imply that French and Moroccan economies will be the same in 2050, but only that the degree of total interdependency between sectors will be the same in Morocco in 2050 as the French today. To achieve this 'marginal convergence', the technical coefficients of the current Moroccan I-O table have been progressively and slowly adapted, but at the end of the adjustment (in 2050) the internal structure of the Moroccan economy does not coincide with that of France; the coincidence between the two I-O tables is limited to the degree of the total interdependency of each sector.

There is a second weakness in this kind of simulation that is often criticised by experts and academics: frequently, various scenarios about import dependency of CSP components are drawn, but they are just speculative assumptions and they are not based on the experience of the stakeholders (firms, governments and international institutions). As part of the potential for industrial clustering of CSP that this research is promoting, we are incorporating a new definition of the scenarios of dependence on imports from Morocco in terms of CSP components. In this paper, we have used the results of an expert survey to find out which components are best suited to be produced directly by Moroccan industries in the future (a detailed analysis of this survey can be found in [2]). In this way, we can get a more realistic picture of the effects of the installation and production of CSP components on the Moroccan economy. Recently, other authors have carried out similar surveys in the context of RES investments, using the technique of 'interviews in depth' in a certain number of international conferences of the CSP sector such as Madrid, 2011, or New Delhi, 2012 [23,24]. Their results have served to verify the robustness of the answers we got in our survey.

The survey is divided into two parts, the first dealing with technical issues related to CSP industry development. The aim of this section was to ask experts to identify those specific production stages and activities that could serve as a starting point for the genesis of a local CSP industry in Morocco. In order to select the items and questions for this section, we considered the most relevant stages along the specific value-added chain for CSP component production and assembly. The second part relates to identifying the barriers to, and comparative advantages of, Morocco as an Foreign Direct Investment target for potential international investors. In relation to this section, and with the intention of building up a logical structure for the survey, we included all the relevant issues in the context of international capital flows.

After a pre-test with 5 experts, the survey was conducted in April and May 2014 using an electronic questionnaire. A group of 40 experts highly involved in the sector were interviewed. The levels of self-assessed experience and knowledge of the renewable energy sector in general and CSP were very high, yielding a score of 4.3/5. The respondents were contacted individually by the research team using a snowball procedure and freely available information about key companies in the CSP sector.

\section{Electricity Demand in Morocco and Electrical Power Installations}

In the context of the Mediterranean Solar Plan (MSP) [5] and the Moroccan's government 20-20-20 plan, we merged different forecasts of electrical energy demand for the next 50 years. We noted that, across sources, analysts used a simple model of electricity demand driven by increasing GDP per capita. We consulted the forecasts of the International Energy Agency, the Ministry of Energy and Mines of Morocco and the REACCESS Project. Obviously, the trends drawn by these analysts are very similar (see more details in $[25,26]$ ). Finally, we chose to define three scenarios, taking the median for each year from the three sources (see Figure 1). 


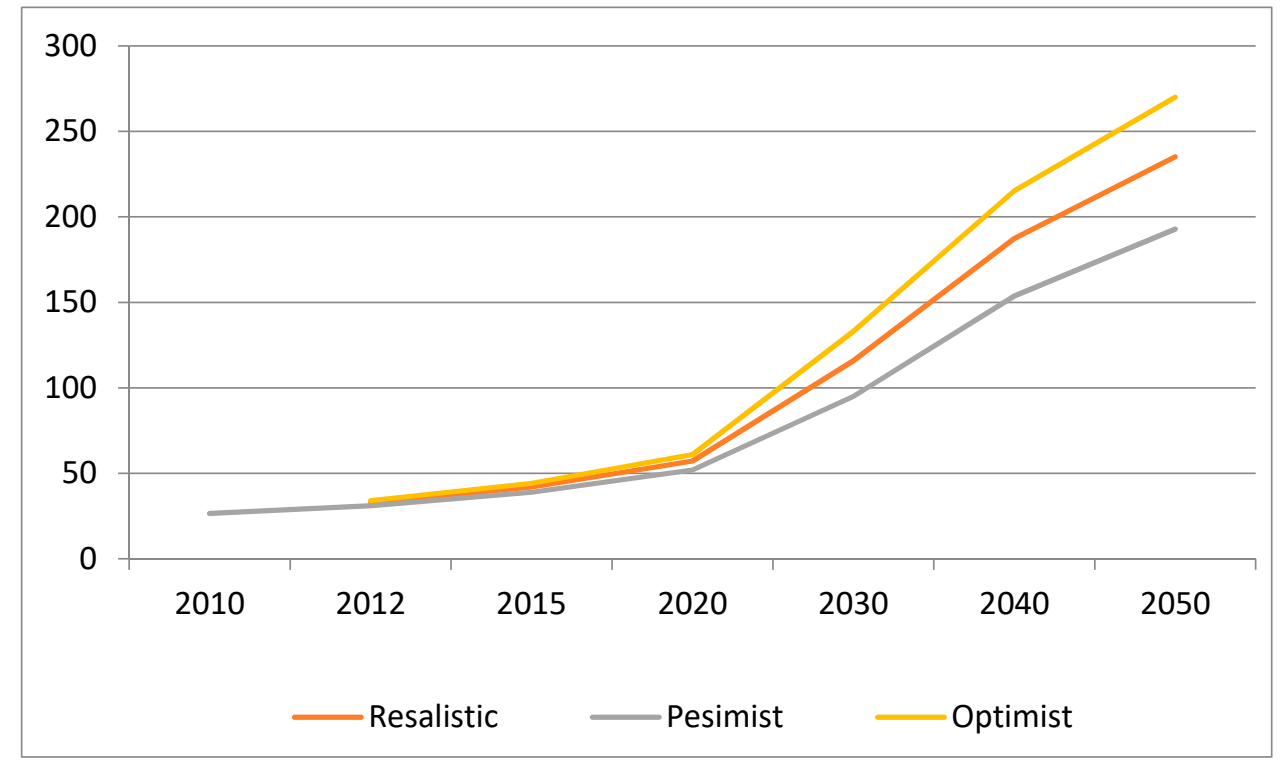

Figure 1. Electricity demand in Morocco for 2010-2050. Source: own calculations from IEA [27], Ministry of Energy of Morocco and REACCESS data.

In our simulation the initial electricity demand is around 31 TWh in 2012, reaching 235, 193 or $270 \mathrm{TWh}$ in the realistic, pessimist and optimist scenarios, respectively, for 2050.

Linked to these scenarios, and considering the objectives marked by MASEN, we can now design the necessary electricity power installation to covert this demand. Using the so-called "realistic scenario" and focusing on renewable energies, we planned the bellow mix of installed electricity power (see Table 1).

Table 1. Installed electricity power by renewable energy sources (RES) in MW: “REALISTIC SCENARIO".

\begin{tabular}{ccccc}
\hline & $\begin{array}{c}\text { CSP } \\
\text { (PARAB. Through) }\end{array}$ & Wind Power & Photovoltaic & Total \\
\hline 2010 & 20 & 284 & 13 & 317 \\
\hline 2012 & 20 & 1192 & 20 & 1232 \\
\hline 2015 & 225 & 1595 & 50 & 1870 \\
\hline 2020 & 416 & 2000 & 80 & 2496 \\
\hline 2030 & 1299 & 3390 & 128 & 4816 \\
\hline 2040 & 2893 & 5777 & 205 & 8875 \\
\hline \multicolumn{5}{r}{ Source: own calculations. } \\
\end{tabular}

To design this power mix, we took the results of the FEMISE Network research project [23], where some assumptions about the capacity factor for each technology played a crucial role.

\section{Designing Import Scenarios of CSP Components}

A survey was conducted among experts to map out the simulation scenarios for the dependence on imports of CSP components in Morocco.

In the first question, the answers allow us to establish what the current situation is, specifically through the answers to the following question: "Which parts of the value chain of CSP technology are suitable NOW for local manufacturing?" We obtained the following results (see Figure 2): 


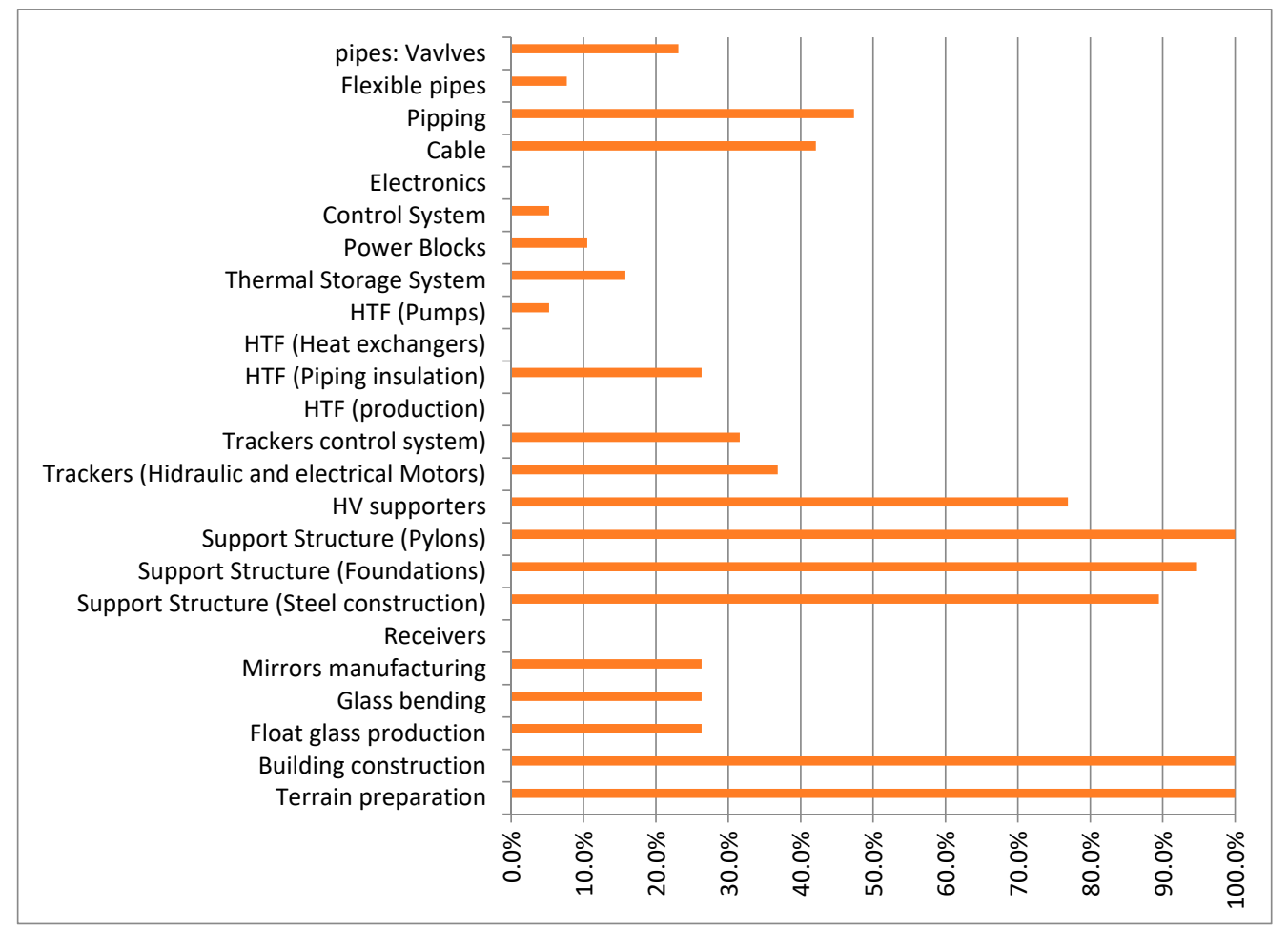

Figure 2. Percent of value chain of Concentrated Solar Power (CSP) components deliverable by Moroccan industries. Source: FEMISE 35-05 research project survey.

From the results of this survey, in the scenario called "business as usual" (BAU), we can establish that construction and terrain preparation can almost be totally produced by domestic Moroccan industries. The answer to this question implies that they can produce these components, but it does not necessary mean that they are producing them in their current projects. As in the case of some specific foundations and pylons, foreign industries will be involved. In addition, storage and power block components show the greatest dependency on imports. In the case of the solar field (mirrors, blending glasses, etc.), a partial dependence is assumed - around $50 \%$ of components coming from abroad (see Table 2).

Table 2. Percent of import components: Business as Usual Scenario.

\begin{tabular}{ccccccc}
\hline \% of Total Cost & Component Group & $\mathbf{2 0 1 0}$ & $\mathbf{2 0 2 0}$ & $\mathbf{2 0 3 0}$ & $\mathbf{2 0 4 0}$ & $\mathbf{2 0 5 0}$ \\
\hline $43.4 \%$ & Solar Field & $57 \%$ & $56.7 \%$ & $56.7 \%$ & $56.7 \%$ & $56.7 \%$ \\
\hline $10.6 \%$ & Power block & $89.2 \%$ & $89.2 \%$ & $89.2 \%$ & $89.2 \%$ & $89.2 \%$ \\
\hline $4.3 \%$ & Terrain & $0.0 \%$ & $0.0 \%$ & $0.0 \%$ & $0.0 \%$ & $0.0 \%$ \\
\hline $19.11 \%$ & Storage & $84.7 \%$ & $84.7 \%$ & $84.7 \%$ & $84.7 \%$ & $84.7 \%$ \\
\hline $1.1 \%$ & Construction & $22.0 \%$ & $22.0 \%$ & $22.0 \%$ & $22.0 \%$ & $22.0 \%$ \\
\hline $11.6 \%$ & Engineering & $100.0 \%$ & $100.0 \%$ & $100.0 \%$ & $100.0 \%$ & $100.0 \%$ \\
\hline $9.9 \%$ & Others & $0.0 \%$ & $0.0 \%$ & $0.0 \%$ & $0.0 \%$ & $0.0 \%$ \\
\hline
\end{tabular}

Source: own calculations.

In order to understand the prospect for the domestic production of these components in the future, the following question was formulated: "Which parts of the value chain of CSP technology would be suitable in the next decade for local manufacturing and under what scenario of progress/changes in the economic/political/social environment?" The respondents reported the following results in Table 3: 
Table 3. Scenarios of change for possible local manufacturing by component.

\begin{tabular}{|c|c|c|c|c|c|c|}
\hline & In Any Case & $\begin{array}{l}\text { Significant } \\
\text { Changes } \\
\text { (1) }\end{array}$ & $\begin{array}{l}\text { Modest } \\
\text { Changes } \\
\text { (2) }\end{array}$ & $\begin{array}{c}\text { Minor } \\
\text { Changes } \\
\text { (3) }\end{array}$ & $(2)+(3)$ & $\begin{array}{l}\text { (1) }+(2)+ \\
\text { (3) }\end{array}$ \\
\hline Terrain Preparation & $9.1 \%$ & $18.2 \%$ & $0.0 \%$ & $72.7 \%$ & $72.7 \%$ & $90.9 \%$ \\
\hline $\begin{array}{l}\text { Building } \\
\text { Construction }\end{array}$ & $0.0 \%$ & $18.2 \%$ & $0.0 \%$ & $81.8 \%$ & $81.8 \%$ & $100.0 \%$ \\
\hline $\begin{array}{l}\text { Float Glass } \\
\text { Production }\end{array}$ & $0.0 \%$ & $22.2 \%$ & $50.0 \%$ & $27.8 \%$ & $77.8 \%$ & $100.0 \%$ \\
\hline Glass Bending & $5.3 \%$ & $15.8 \%$ & $63.2 \%$ & $15.8 \%$ & $78.9 \%$ & $94.7 \%$ \\
\hline $\begin{array}{c}\text { Mirror } \\
\text { Manufacturing }\end{array}$ & $5.9 \%$ & $17.6 \%$ & $52.9 \%$ & $23.5 \%$ & $76.5 \%$ & $94.1 \%$ \\
\hline Receivers & $5.3 \%$ & $68.4 \%$ & $21.1 \%$ & $5.3 \%$ & $26.3 \%$ & $94.7 \%$ \\
\hline $\begin{array}{l}\text { Support Structure } \\
\text { (Steel Construction) }\end{array}$ & $23.5 \%$ & $11.8 \%$ & $29.4 \%$ & $35.3 \%$ & $64.7 \%$ & $76.5 \%$ \\
\hline $\begin{array}{l}\text { Support Structure } \\
\text { (Foundations) }\end{array}$ & $25.0 \%$ & $6.3 \%$ & $12.5 \%$ & $56.3 \%$ & $68.8 \%$ & $75.0 \%$ \\
\hline $\begin{array}{l}\text { Support Structure } \\
\text { (Pylons) }\end{array}$ & $26.7 \%$ & $6.7 \%$ & $13.3 \%$ & $53.3 \%$ & $66.7 \%$ & $73.3 \%$ \\
\hline Control System & $7.7 \%$ & $53.8 \%$ & $35.8 \%$ & $0.0 \%$ & $38.5 \%$ & $92.3 \%$ \\
\hline $\begin{array}{l}\text { Trackers (Hydraulic } \\
\text { and Electric Motors) }\end{array}$ & $7.7 \%$ & $15.4 \%$ & $69.2 \%$ & $7.7 \%$ & $76.9 \%$ & $92.3 \%$ \\
\hline HV Supporters & $0.0 \%$ & $27.3 \%$ & $27.3 \%$ & $45.5 \%$ & $72.7 \%$ & $100.0 \%$ \\
\hline HTF (Production) & $15.4 \%$ & $38.5 \%$ & $30.8 \%$ & $15.4 \%$ & $46.2 \%$ & $84.6 \%$ \\
\hline $\begin{array}{l}\text { HTF (Piping } \\
\text { Insulation) }\end{array}$ & $0.0 \%$ & $38.5 \%$ & $23.1 \%$ & $38.5 \%$ & $61.5 \%$ & $100.0 \%$ \\
\hline $\begin{array}{l}\text { HTF (Heat } \\
\text { Exchangers) }\end{array}$ & $10.5 \%$ & $36.8 \%$ & $47.4 \%$ & $5.3 \%$ & $52.6 \%$ & $89.5 \%$ \\
\hline HTF (Pumps) & $15.8 \%$ & $26.3 \%$ & $52.6 \%$ & $5.3 \%$ & $57.9 \%$ & $84.2 \%$ \\
\hline $\begin{array}{l}\text { Thermal Storage } \\
\text { System }\end{array}$ & $10.5 \%$ & $57.9 \%$ & $31.6 \%$ & $0.0 \%$ & $31.6 \%$ & $89.5 \%$ \\
\hline Power Blocks & $15.8 \%$ & $26.3 \%$ & $52.6 \%$ & $5.3 \%$ & $57.9 \%$ & $84.2 \%$ \\
\hline Control System & $16.7 \%$ & $44.4 \%$ & $38.9 \%$ & $0.0 \%$ & $38.9 \%$ & $83.3 \%$ \\
\hline Electronics & $5.6 \%$ & $50.0 \%$ & $38.9 \%$ & $5.6 \%$ & $44.4 \%$ & $94.4 \%$ \\
\hline Cable & $18.8 \%$ & $18.8 \%$ & $31.3 \%$ & $31.3 \%$ & $62.5 \%$ & $81.3 \%$ \\
\hline Piping & $18.8 \%$ & $18.8 \%$ & $12.5 \%$ & $50.0 \%$ & $62.5 \%$ & $81.3 \%$ \\
\hline Flexible Pipes & $0.0 \%$ & $50.0 \%$ & $16.7 \%$ & $33.3 \%$ & $50.0 \%$ & $100.0 \%$ \\
\hline Pipes: Valves & $8.3 \%$ & $41.7 \%$ & $33.3 \%$ & $16.7 \%$ & $50.0 \%$ & $91.7 \%$ \\
\hline
\end{tabular}

Bold characters: percentages over 65\%. Source: FEMISE 35-05 research project survey and own calculations.

Taking into account a consensus of up to $65 \%$ in the case of "minor or modest changes" and up to $80 \%$ for "significant progress" in the above scales, we can draw the following alternative import dependency scenarios for the main groups of CSP components (see Tables 4 and 5): 
Table 4. Percent of import components: more likely scenario (with modest or minor changes).

\begin{tabular}{ccccc}
\hline & $\mathbf{2 0 2 0}$ & $\mathbf{2 0 3 0}$ & $\mathbf{2 0 4 0}$ & $\mathbf{2 0 5 0}$ \\
\hline Solar Field & $43.6 \%$ & $30.6 \%$ & $30.6 \%$ & $30.6 \%$ \\
\hline Power Block & $89.2 \%$ & $89.2 \%$ & $89.2 \%$ & $89.2 \%$ \\
\hline Terrain & $0.0 \%$ & $0.0 \%$ & $0.0 \%$ & $0.0 \%$ \\
\hline Storage & $84.7 \%$ & $84.7 \%$ & $84.7 \%$ & $84.7 \%$ \\
\hline Construction & $22.0 \%$ & $22.0 \%$ & $22.0 \%$ & $22.0 \%$ \\
\hline Engineering & $100.0 \%$ & $100.0 \%$ & $100.0 \%$ & $100.0 \%$ \\
\hline Contingencies & $0.0 \%$ & $0.0 \%$ & $0.0 \%$ & $0.0 \%$ \\
\hline \multicolumn{5}{c}{ Source: own calculations. } \\
\hline
\end{tabular}

Table 5. Percent of import components: more favourable scenario (with significant changes).

\begin{tabular}{ccccc}
\hline & $\mathbf{2 0 2 0}$ & $\mathbf{2 0 3 0}$ & $\mathbf{2 0 4 0}$ & $\mathbf{2 0 5 0}$ \\
\hline Solar Field & $29.7 \%$ & $2.8 \%$ & $2.8 \%$ & $2.8 \%$ \\
\hline Power Block & $44.6 \%$ & $0.0 \%$ & $0.0 \%$ & $0.0 \%$ \\
\hline Terrain & $0.0 \%$ & $0.0 \%$ & $0.0 \%$ & $0.0 \%$ \\
\hline Storage & $42.3 \%$ & $0.0 \%$ & $0.0 \%$ & $0.0 \%$ \\
\hline Construction & $11.0 \%$ & $0.0 \%$ & $0.0 \%$ & $0.0 \%$ \\
\hline Engineering & $100.0 \%$ & $100.0 \%$ & $100.0 \%$ & $100.0 \%$ \\
\hline Contingencies & $0.0 \%$ & $0.0 \%$ & $0.0 \%$ & $0.0 \%$ \\
\hline
\end{tabular}

\section{Simulation Results}

\subsection{Investment by Technology and by Scenario of Imports}

The first output that we can highlight as a result of our simulation scenarios is the investment amount required to install the RES to generate electric power implied by the previous information, taking into account the part that is going to be directly produced by Moroccan industries and the part that is imported.

Several previous projects (for example, Ain Beni Mathar) were financed by the World Bank and by the African Bank for Development. In the last "summary of discussion" of this institution, regarding the Ouarzazate Plant of CSP projected in Morocco (November 15th 2011), the executive directors approved funding for this project. However, "directors acknowledged the various risks associated with the project, given the novelty of the technology and uncertainty of demand. Finally, Executive Directors encouraged close donor collaboration between co-financiers of the project" ([28]).

Undeniably, an important debate about the way to finance this investment is crucial, but this issue is clearly out of the scope of this investigation, given that we focus on the macroeconomic effects of CSP deployment in Morocco.

Essentially, for each decade, there is a progressive amount of investment required to reach the targets in the production mix fixed in the previous stage of this simulation (see Table 6). The total share of Moroccan industries in this project is related to the "import dependency scenario" chosen. Therefore, at the end of the simulating horizon, $98 \%$ of the investment could be directly applied by Moroccan industries in the most favourable scenario, from $45 \%$ in the "more realistic scenario" to $36 \%$ in the "Business As Usual (BAU) Scenario". 
Table 6. Total investment in Morocco (EUR).

\begin{tabular}{cccccc}
\hline Total Investment & $\mathbf{2 0 1 0}$ & $\mathbf{2 0 2 0}$ & $\mathbf{2 0 3 0}$ & $\mathbf{2 0 4 0}$ & $\mathbf{2 0 5 0}$ \\
\hline PARAB. Through & 106,335 & 669,053 & $2,567,373$ & $4,339,444$ & $4,923,042$ \\
Wind Power & 254,035 & 302,466 & 917,897 & $1,484,812$ & 966,106 \\
Photovoltaic & 47,600 & 71,559 & 88,524 & 126,516 & 192,324 \\
Total Investment & 407,970 & $1,043,078$ & $3,573,795$ & $5,950,772$ & $6,081,473$ \\
SC. 1: B.A.U. & & & & & \\
National (in Morocco) & & & & & \\
PARAB. Through & 16,254 & 250,274 & 945,000 & $1,592,965$ & $1,805,271$ \\
Wind Power & 153,533 & 214,096 & 712,955 & $1,235,906$ & 844,303 \\
Photovoltaic & 14,477 & 37,824 & 60,555 & 97,416 & 157,963 \\
$\quad$ Total & 184,263 & 502,194 & $1,718,510$ & $2,926,287$ & $2,807,537$ \\
SC. 2: More Likely & $\mathbf{2 0 1 0}$ & $\mathbf{2 0 2 0}$ & $\mathbf{2 0 3 0}$ & $\mathbf{2 0 4 0}$ & $\mathbf{2 0 5 0}$ \\
National (in Morocco) & & & & & \\
PARAB. Through & 16,254 & 281,635 & $1,173,936$ & $1,966,920$ & $2,219,633$ \\
Wind Power & 153,533 & 214,096 & 712,955 & $1,235,906$ & 844,303 \\
Photovoltaic & 14,477 & 37,824 & 60,555 & 97,416 & 157,963 \\
$\quad$ Total & 184,263 & 533,555 & $1,947,447$ & $3,300,242$ & $3,221,899$ \\
SC. 3: Significant & $\mathbf{2 0 1 0}$ & $\mathbf{2 0 2 0}$ & $\mathbf{2 0 3 0}$ & $\mathbf{2 0 4 0}$ & $\mathbf{2 0 5 0}$ \\
Changes & & & & & \\
National (in Morocco) & & & & \\
PARAB. Through & 16,254 & 441,157 & $2,500,364$ & $4,261,331$ & $4,857,347$ \\
Wind Power & 153,533 & 214,096 & 712,955 & $1,235,906$ & 844,303 \\
Photovoltaic & 14,477 & 37,824 & 60,555 & 97,416 & 157,963 \\
$\quad$ Total & 184,263 & $\mathbf{6 9 3 , 0 7 7}$ & $3,273,874$ & $5,594,653$ & $5,859,613$ \\
\hline
\end{tabular}

Source: own calculations.

All these figures are related to the whole decade where they appear. The rest of the RES technologies have been unchanged in terms of domestic/import dependency. They simply serve as a comparison point with possible CSP progression.

\subsection{Effects on Valued Added and Employment from the CSP Technology Installation in Morocco}

Considering the three chosen import scenarios, we have found a total effect on Moroccan GDP that moves from $1.27 \%$ to $1.77 \%$ for 2050 . The differences between scenarios are very small in terms of GDP between BAU and "More likely" (around 0.15\%). Comparing BAU with the "significant changes Scenario", these differences can be around 0.5 (see Table 7).

Table 7. Economic impact of RES investments in Morocco.

\begin{tabular}{|c|c|c|c|c|c|}
\hline \multicolumn{6}{|l|}{ Business as Usual } \\
\hline & 2010 & 2020 & 2030 & 2040 & 2050 \\
\hline Added Value (K EUR) & 137,936 & 350,315 & $1,123,754$ & $2,132,626$ & $2,026,956$ \\
\hline $\begin{array}{l}\text { Employment } \\
\text { (Employees) }\end{array}$ & 35,989 & 85,790 & 247,045 & 409,245 & 342,448 \\
\hline Total Effect (A.V.)/GDP & $0.18 \%$ & $0.38 \%$ & $1.02 \%$ & $1.61 \%$ & $1.27 \%$ \\
\hline \multicolumn{6}{|c|}{ More Likely Scenario (Minor or Moderate Change) } \\
\hline & 2010 & 2020 & 2030 & 2040 & 2050 \\
\hline Added Value (K EUR) & 137,936 & 364,877 & $1,275,268$ & $2,421,853$ & $2,405,436$ \\
\hline $\begin{array}{l}\text { Employment } \\
\text { (Employees) }\end{array}$ & 35,989 & 90,463 & 291,114 & 482,959 & 424,764 \\
\hline Total Effect (A.V.)/GDP & $0.18 \%$ & $0.40 \%$ & $1.15 \%$ & $1.83 \%$ & $1.51 \%$ \\
\hline \multicolumn{6}{|c|}{ Significant Changes Scenario } \\
\hline & 2010 & 2020 & 2030 & 2040 & 2050 \\
\hline Added Value (K EUR) & 137,936 & 385,481 & $1,445,661$ & $2,739,569$ & $2,815,694$ \\
\hline $\begin{array}{l}\text { Employment } \\
\text { (Employees) }\end{array}$ & 35,989 & 96,491 & 339,535 & 562,931 & 513,427 \\
\hline Total Effect (A.V.)/GDP & $0.18 \%$ & $0.42 \%$ & $1.31 \%$ & $2.07 \%$ & $1.77 \%$ \\
\hline
\end{tabular}

Source: own calculations.

In all three scenarios, there are large differences in terms of the number of employees. In the third scenario, the creation of a semi-complete industry of CSP components in Morocco is related to an increase in the number of employments, around 85,000 on average for the entire simulation horizon. 
In the case of the second scenario, with only a partial installation of this type of industry in the country, the average employment could be around 40,954 people.

\section{Discussion}

We have estimated the economic impact of CSP investment in Morocco under different scenarios of import dependency on the components of these plants. These scenarios of dependency are derived from the results of an in-depth survey of the sector stakeholders, reducing the frequent level of speculation in these investigations.

From the results of the experts' survey, we can highlight that a local CSP industry in Morocco presents a likelihood of 7.15 out of $15(47.7 \%)$, but, if we look at the future, given certain "environment" adjustments during the next decade, the same experts agree that this likelihood increases to an average of 10 over $15(70 \%)$, (or 11/15 (73\%) in median terms).

It is extremely interesting that a CSP industry in Morocco, both now and in the next decade, when assessing opportunities, is best assessed by those who have experienced recent activity in Morocco than those who have not had any previous business in the area. In this sense, the possibilities of establishing a CSP industry in the country rise to around 12.5 (over 15) in the view of those entrepreneurs operating in Morocco, and a valuation of only 10 from those who, for the moment, have no business experience in the area.

In terms of the implications of these results in relation to the potential economic effect and the CSP value chain, three main activities now seem suitable for local manufacturing: the construction of factories, the construction of solar structures and the manufacture of minor complementary components such as pipes and cables. As expected, all these activities are clearly those of lower technological requirements and could easily match the actual potential of Moroccan industry. In addition, and more importantly, we must consider that every CSP manufacturing process could be locally implemented in the next decade given the appropriate changes. Besides, under a feasible scenario of minor or moderate changes, 15 out of the 23 stages could be locally implemented.

With this information, we have a progressive amount of investment required to achieve the targets in the production mix set in the previous stage of this simulation. The total participation of Moroccan industries in this project is related to the "import dependency scenario" chosen. Thus, at the end of the simulating horizon, $98 \%$ of the investment could be applied directly by Moroccan industries in the most favourable scenario, from $45 \%$ in the "more realistic scenario" to $36 \%$ in the "BAU Scenario".

Considering a consensus of up to $65 \%$ in the case of "minor or modest changes" and up to $80 \%$ in the case of "significant progress" for the previous scales, we can draw the following alternative scenarios of import dependency and economic effects on the Moroccan economy:

(a) We found a total effect on Moroccan annual GDP that moves from 1.27\% to $1.77 \%$ for 2050 . The differences between scenarios are very small in terms of GDP between BAU and "More likely" (around $0.15 \%$ ). Comparing BAU with the "significant changes Scenario", these differences can be around 0.5 per point of GDP.

(b) In all three scenarios, there are large differences in terms of the number of employees. In the third scenario, the creation of a semi-complete industry of CSP components in Morocco is related to an increase in the number of jobs, around 85,000 (average for the entire simulation horizon). In the case of the second scenario, with just a partial installation of this kind of industry in the country, the employment average could be around 40,954 people.

Therefore, an important debate about the way to finance this investment is crucial, but this issue is clearly out of the scope of this investigation, given that we focus on the macroeconomic effects of CSP deployment in Morocco. Furthermore, the total amount of investment in these types of technologies in the next year will have a crucial role in the development of a more competitive industry compared with traditional energy sources. The well-known learning curve that is present in all of the simulations about the future of RES is totally dependent on the new installed capacity of each energy source and this is clearly connected to the sine qua non conditions of market transparency, a reduction in uncertainty 
about taxation and subventions and the political stability of the area where these technologies can be installed, etc. All these issues could create a totally different picture in the future if they are not conveniently achieved, but this analysis lies outside the scope of this article.

Comparing with the results in de Arce et al. (2012), our new estimates indicate that the use of CSP has slightly greater consequences in terms of the economic effect on the Moroccan economy: the impact on GDP would be about $0.13 \%$ higher with CSP than PV and the number of jobs created are very similar at the end of the forecast horizon. The wind farm scenario continues to make a clear difference: the impact would represent $1.92 \%$ of GDP in 2050 compared to a $1.77 \%$ average of the two alternative sources.

Unfortunately, we cannot establish comparisons with other literature studies because of the novelty of these results in the context of the Moroccan economy. The only (very specific) reference we can use is de Arce et al. [1], where the definitions of the scenarios were more theoretically driven. In this article, we assume more accurately assumptions about the international dependency of Morocco in terms of the self-production of technical components in the CSP industry, producing a double effect: a reduction in dependency, and a significant increase in the GDP effects compared with the previously discussed simulation.

\section{Conclusions}

The macroeconomic results obtained from investment in RES in Morocco are clearly significant, both in terms of job creation and contribution to GDP growth, and in terms of the contribution to the creation of an energy collection system that is less dependent on the outside world. At the same time, this investment allows Morocco to exploit one of its international comparative advantages as a source of clean energy for the countries around it, especially those of the European Union. Evidently, the contribution to the generation of clean and sustainable growth alternatives for the whole planet is, in the context of a commitment to RES, an unquestionable point of support.

Considering the three chosen import scenarios, we found a total effect on Moroccan GDP that increases from $1.27 \%$ to $1.77 \%$ for 2050 . The differences between scenarios are very small in terms of GDP between BAU and "More likely" (around 0.15\%). When comparing BAU with the "significant changes Scenario", these differences can be around 0.5.

In all three scenarios, there are large differences in terms of the number of employees. In the third scenario, the creation of a semi-complete industry of CSP components in Morocco is related to an increase in the number of jobs, around 85,000 (average for the entire simulation horizon). In the case of the second scenario, with just a partial installation of this kind of industry in the country, the employment average could be around 40,954 people.

Undeniably, as highlighted in [28,29], an important debate about the way to finance this investment is crucial, but this issue is clearly out of the scope of this investigation, given that we focus on the macroeconomic effects of CSP deployment in Morocco.

We are aware that the expert survey used in this article may be somewhat outdated (it was conducted in 2014). In any case, we believe that the main conclusions of the survey by investors, political actors and stakeholders in general are still valid, and there is no other similar survey directly related to the Moroccan case to date. As mentioned in the text, there are some other surveys related to the European Union. In general, the conclusions of these surveys are similar, with due precautions to be considered, as they do not specifically refer to Morocco, which makes the survey used in this research more useful.

There are various restrictions related to political, regulatory and investment risks perceived, as evidenced by the results obtained in the survey used in this research. There are also some uncertainties about the possible evolution of the country in terms of its autonomy to develop and produce technical components in this very specific industry, which has so far been dominated mainly by German, Spanish and American developers. As shown in $[1,12,13]$, the evolution of the industry itself (the growth in the number of solar plants installed of this type throughout the world) will allow not only an exponential 
reduction in costs, but also the creation of national industries for the internal production of components. Under these conditions, the effects on the Moroccan economy of investment in CSP could be even more beneficial.

Author Contributions: Both authors (R.M. and R.D.A.) have been in charge of all the aspects of this article, including theoretical background, analytical issues and article writing and edition. All authors have read and agreed to the published version of the manuscript.

Funding: This research was funded by FEMISE Contract N. FEM35-05.

Acknowledgments: We thank the FEMISE Network for its financial assistance and the Director of AGREEM, Alex Lorca, for his consistently interesting suggestions.

Conflicts of Interest: The Authors declare no conflict of interest.

\section{Abbreviations}

$\begin{array}{ll}\text { BAU } & \text { Business as Usual } \\ \text { CSP } & \text { Concentrated Solar Power } \\ \text { DI-O } & \text { Dynamic Input-Output } \\ \text { DNI } & \text { Density of Normal Irradiation } \\ \text { FEMISE } & \text { Forum Euromediterranéen Institutes de Sciences Economiques } \\ \text { GDP } & \text { Gross Domestic Product } \\ \text { IEA } & \text { International Energy Agency } \\ \text { MASEN } & \text { Agence Marocaine pour l'Energie Durable } \\ \text { MENA } & \text { Middle East and North Africa } \\ \text { MSP } & \text { Mediterranean Solar Plan } \\ \text { PV } & \text { Photovoltaic } \\ \text { RES } & \text { Renewable Energy Sources } \\ \text { SDG } & \text { Sustainable Development Goals } \\ \text { TWh } & \text { Terawatt-Hour }\end{array}$

\section{Appendix A}

Table A1. Investment for 1MW of installed power using CSP technology.

\begin{tabular}{|c|c|c|c|c|c|}
\hline & 2010 & 2020 & 2030 & 2040 & 2050 \\
\hline \multicolumn{6}{|c|}{ Investment } \\
\hline Solar Field & 2469.7 & 1262.0 & 995.6 & 900.6 & 845.3 \\
\hline Power Block & 1113.8 & 979.3 & 935.7 & 917.9 & 906.8 \\
\hline Terrain & 24.2 & 24.2 & 24.2 & 24.2 & 24.2 \\
\hline Storage & 663.7 & 390.2 & 323.4 & 298.7 & 284.1 \\
\hline Construction & 531.7 & 531.7 & 531.7 & 531.7 & 531.7 \\
\hline Engineering & 256.8 & 159.1 & 48.4 & 24.1 & 11.6 \\
\hline Contingencies & 256.8 & 159.1 & 48.4 & 24.1 & 11.6 \\
\hline $\begin{array}{l}\text { Total } \\
\text { \% Import }\end{array}$ & 5316.7 & 3505.5 & 2907.4 & 2721.3 & 2615.3 \\
\hline Solar Field & $100.0 \%$ & $56.7 \%$ & $56.7 \%$ & $56.7 \%$ & $56.7 \%$ \\
\hline Power Block & $100.0 \%$ & $89.2 \%$ & $89.2 \%$ & $89.2 \%$ & $89.2 \%$ \\
\hline Terrain & $0.0 \%$ & $0.0 \%$ & $0.0 \%$ & $0.0 \%$ & $0.0 \%$ \\
\hline Storage & $100.0 \%$ & $84.7 \%$ & $84.7 \%$ & $84.7 \%$ & $84.7 \%$ \\
\hline Construction & $0.0 \%$ & $22.0 \%$ & $22.0 \%$ & $22.0 \%$ & $22.0 \%$ \\
\hline Engineering & $100.0 \%$ & $100.0 \%$ & $100.0 \%$ & $100.0 \%$ & $100.0 \%$ \\
\hline Contingencies & $0.0 \%$ & $0.0 \%$ & $0.0 \%$ & $0.0 \%$ & $0.0 \%$ \\
\hline \multicolumn{6}{|c|}{$\begin{array}{l}\text { National (Morocco) } \\
\text { (K EUR) }\end{array}$} \\
\hline Solar Field & 0.0 & 547.1 & 431.6 & 390.4 & 366.4 \\
\hline Power Block & 0.0 & 106.2 & 101.5 & 99.6 & 98.4 \\
\hline Terrain & 24.2 & 24.2 & 24.2 & 24.2 & 24.2 \\
\hline Storage & 0.0 & 59.9 & 49.6 & 45.8 & 43.6 \\
\hline Construction & 531.7 & 414.8 & 414.8 & 414.8 & 414.8 \\
\hline Engineering & 0.0 & 0.0 & 0.0 & 0.0 & 0.0 \\
\hline Contingencies & 256.8 & 159.1 & 48.4 & 24.1 & 11.6 \\
\hline Total & 812.7 & 1311.3 & 1070.2 & 999.0 & 959.0 \\
\hline
\end{tabular}


Table A2. Investment for $1 \mathrm{MW}$ of installed power using wind power technology.

\begin{tabular}{|c|c|c|c|c|c|}
\hline & 2010 & 2020 & 2030 & 2040 & 2050 \\
\hline \multicolumn{6}{|l|}{$\begin{array}{l}\text { Investment } \\
\text { (K EUR) }\end{array}$} \\
\hline Electric Installation + Network Connection & 85.3 & 83.6 & 82.7 & 82.2 & 81.9 \\
\hline Tower (Steel) & 103.4 & 101.3 & 100.2 & 99.6 & 99.2 \\
\hline Turbine & 583.8 & 469.6 & 418.4 & 392.0 & 377.5 \\
\hline Land (Terrain) & 54.3 & 36.2 & 16.1 & 10.7 & 7.2 \\
\hline Storage & 0.0 & 0.0 & 0.0 & 0.0 & 0.0 \\
\hline Construction & 38.6 & 31.9 & 28.9 & 27.4 & 26.5 \\
\hline Engineering & 14.5 & 12.0 & 7.1 & 5.0 & 3.4 \\
\hline Transports & 14.5 & 12.0 & 7.1 & 5.0 & 3.4 \\
\hline \multicolumn{6}{|l|}{ \% Import } \\
\hline Electric Installation + Network Connection & $50.0 \%$ & $37.0 \%$ & $27.4 \%$ & $20.3 \%$ & $15.0 \%$ \\
\hline Tower (Steel) & $0.0 \%$ & $0.0 \%$ & $0.0 \%$ & $0.0 \%$ & $0.0 \%$ \\
\hline Turbine & $50.0 \%$ & $37.0 \%$ & $27.4 \%$ & $20.3 \%$ & $15.0 \%$ \\
\hline Land (Terrain) & $0.0 \%$ & $0.0 \%$ & $0.0 \%$ & $0.0 \%$ & $0.0 \%$ \\
\hline Storage & $0.0 \%$ & $0.0 \%$ & $0.0 \%$ & $0.0 \%$ & $0.0 \%$ \\
\hline Construction & $50.0 \%$ & $42.0 \%$ & $35.4 \%$ & $29.7 \%$ & $25.0 \%$ \\
\hline Engineering & $0.0 \%$ & $0.0 \%$ & $0.0 \%$ & $0.0 \%$ & $0.0 \%$ \\
\hline Transports & $0.0 \%$ & $0.0 \%$ & $0.0 \%$ & $0.0 \%$ & $0.0 \%$ \\
\hline \multicolumn{6}{|l|}{$\begin{array}{c}\text { National (Morocco) } \\
\text { (K EUR) }\end{array}$} \\
\hline Electric Installation + Network Connection & 42.7 & 52.7 & 60.0 & 65.5 & 69.6 \\
\hline Tower (Steel) & 103.4 & 101.3 & 100.2 & 99.6 & 99.2 \\
\hline Turbine & 291.9 & 295.8 & 303.8 & 312.6 & 320.9 \\
\hline Land (Terrain) & 54.3 & 36.2 & 16.1 & 10.7 & 7.2 \\
\hline Storage & 0.0 & 0.0 & 0.0 & 0.0 & 0.0 \\
\hline Construction & 19.3 & 18.5 & 18.7 & 19.2 & 19.9 \\
\hline Engineering & 14.5 & 12.0 & 7.1 & 5.0 & 3.4 \\
\hline Transports & 14.5 & 12.0 & 7.1 & 5.0 & 3.4 \\
\hline Total & 540.6 & 528.5 & 513.0 & 517.6 & 523.6 \\
\hline
\end{tabular}

Table A3. Investment for 1MW of installed power using photovoltaic technology.

\begin{tabular}{|c|c|c|c|c|c|}
\hline & 2010 & 2020 & 2030 & 2040 & 2050 \\
\hline \multicolumn{6}{|l|}{ Investment } \\
\hline Solar Cell & 1618.4 & 849.4 & 523.4 & 404.8 & 355.2 \\
\hline Other Components & 247.6 & 129.9 & 80.1 & 61.9 & 54.3 \\
\hline Electrical Connections & 14.2 & 7.5 & 4.6 & 3.6 & 3.1 \\
\hline BOS & 805.8 & 422.9 & 260.6 & 201.5 & 176.9 \\
\hline Land & 0.4 & 0.4 & 0.4 & 0.4 & 0.4 \\
\hline Construction and Engineering & 975.2 & 975.2 & 975.2 & 975.2 & 975.2 \\
\hline $\begin{array}{c}\text { Total } \\
\% \text { Import }\end{array}$ & 3661.6 & 2385.3 & 1844.2 & 1647.3 & 1565.1 \\
\hline Solar Cell & $100.0 \%$ & $84.1 \%$ & $70.7 \%$ & $59.5 \%$ & $50.0 \%$ \\
\hline Other Components & $50.0 \%$ & $42.0 \%$ & $35.4 \%$ & $29.7 \%$ & $25.0 \%$ \\
\hline Electrical Connections & $0.0 \%$ & $0.0 \%$ & $0.0 \%$ & $0.0 \%$ & $0.0 \%$ \\
\hline BOS & $100.0 \%$ & $84.1 \%$ & $70.7 \%$ & $59.5 \%$ & $50.0 \%$ \\
\hline LAND & $0.0 \%$ & $0.0 \%$ & $0.0 \%$ & $0.0 \%$ & $0.0 \%$ \\
\hline $\begin{array}{l}\text { Construction and Engineering } \\
\text { National (Morocco) } \\
\text { (K EUR) }\end{array}$ & $0.0 \%$ & $0.0 \%$ & $0.0 \%$ & $0.0 \%$ & $0.0 \%$ \\
\hline Solar Cell & 0.0 & 135.1 & 153.3 & 164.1 & 177.6 \\
\hline Other Components & 123.8 & 75.3 & 51.8 & 43.5 & 40.8 \\
\hline Electrical Connections & 14.2 & 7.5 & 4.6 & 3.6 & 3.1 \\
\hline BOS & 0.0 & 67.3 & 76.3 & 81.7 & 88.4 \\
\hline LAND & 0.4 & 0.4 & 0.4 & 0.4 & 0.4 \\
\hline Construction and Engineering & 975.2 & 975.2 & 975.2 & 975.2 & 975.2 \\
\hline Total & 1113.6 & 1260.8 & 1261.6 & 1268.4 & 1285.5 \\
\hline
\end{tabular}


Table A4. Results for different import dependency scenarios.

\begin{tabular}{|c|c|c|c|c|c|}
\hline \multicolumn{6}{|c|}{ (1) Business as Usual } \\
\hline & 2010 & 2020 & 2030 & 2040 & 2050 \\
\hline \multicolumn{6}{|l|}{ Direct Effect } \\
\hline Production (K EUR) & 529,766 & 935,178 & $2,766,990$ & $4,717,634$ & $3,864,870$ \\
\hline Added Value (K EUR) & 73,572 & 186,601 & 595,919 & $1,114,642$ & $1,040,939$ \\
\hline Employment (Employees) & 11,127 & 41,296 & 111,899 & 177,715 & 158,986 \\
\hline \multicolumn{6}{|l|}{ Indirect Effect } \\
\hline Production (K EUR) & 258,903 & 558,945 & $1,788,553$ & $3,342,566$ & $3,000,262$ \\
\hline Added Value (K EUR) & 64,364 & 163,714 & 527,835 & $1,017,984$ & 986,016 \\
\hline Employment (Employees) & 25,155 & 47,351 & 140,384 & 241,295 & 195,864 \\
\hline \multicolumn{6}{|l|}{ Total Effect } \\
\hline Production (K EUR) & 788,669 & $1,494,124$ & $4,555,543$ & $8,060,201$ & $6,865,132$ \\
\hline Added Value (K EUR) & 137,936 & 350,315 & $1,123,754$ & $2,132,626$ & $2,026,956$ \\
\hline Employment (Employees) & 35,989 & 85,790 & 247,045 & 409,245 & 342,448 \\
\hline PRO-MEMORIAM & 2010 & $2011-2020$ & 2021-2030 & $2031-2040$ & 2041-2050 \\
\hline GDP Morocco (K EUR) & $76,694,200$ & $92,033,040$ & $110,439,648$ & $132,527,578$ & $159,033,093$ \\
\hline Total Effect (A.V.)/GDP & $0.18 \%$ & $0.38 \%$ & $1.02 \%$ & $1.61 \%$ & $1.27 \%$ \\
\hline Employment (Persons) & $10,551,306$ & $10,656,819$ & $10,763,387$ & $10,871,021$ & $10,979,731$ \\
\hline \multicolumn{6}{|c|}{ (2) More Likelihood Scenario (Minor or Moderate Change) } \\
\hline & 2010 & 2020 & 2030 & 2040 & 2050 \\
\hline \multicolumn{6}{|l|}{ Direct Effect } \\
\hline Production (K EUR) & 529,766 & 977,591 & $3,181,256$ & $5,427,892$ & $4,676,915$ \\
\hline Added Value (K EUR) & 73,572 & 194,493 & 677,099 & $1,266,938$ & $1,235,846$ \\
\hline Employment (Employees) & 11,127 & 44,557 & 142,457 & 227,761 & 211,851 \\
\hline \multicolumn{6}{|l|}{ Indirect Effect } \\
\hline Production (K EUR) & 258,903 & 580,415 & $2,014,437$ & $3,769,169$ & $3,545,013$ \\
\hline Added Value (K EUR) & 64,364 & 170,384 & 598,169 & $1,154,916$ & $1,169,590$ \\
\hline Employment (Employees) & 25,155 & 48,763 & 153,894 & 264,963 & 225,314 \\
\hline \multicolumn{6}{|l|}{ Total Effect } \\
\hline Production (K EUR) & 788,669 & $1,558,006$ & $5,195,693$ & $9,197,062$ & $8,221,928$ \\
\hline Added Value (K EUR) & 137,936 & 364,877 & $1,275,268$ & $2,421,853$ & $2,405,436$ \\
\hline Employment (Employees) & 35,989 & 90,463 & 291,114 & 482,959 & 424,764 \\
\hline PRO-MEMORIAM & 2010 & 2011-2020 & $2021-2030$ & $2031-2040$ & $2041-2050$ \\
\hline GDP Morocco (K EUR) & $76,694,200$ & $92,033,040$ & $110,439,648$ & $132,527,578$ & $159,033,093$ \\
\hline Total Effect (A.V.)/GDP & $0.18 \%$ & $0.40 \%$ & $1.15 \%$ & $1.83 \%$ & $1.51 \%$ \\
\hline \multirow[t]{3}{*}{ Employment (persons) } & $10,551,306$ & $10,656,819$ & $10,763,387$ & $10,871,021$ & $10,979,731$ \\
\hline & (3) Significan & it Changes S & cenario & & \\
\hline & 2010 & 2020 & 2030 & 2040 & 2050 \\
\hline \multicolumn{6}{|l|}{ Direct Effect } \\
\hline Production (K EUR) & 529,766 & $1,035,060$ & $3,648,612$ & $6,209,366$ & $5,557,751$ \\
\hline Added Value (K EUR) & 73,572 & 205,578 & 768,269 & $1,434,141$ & $1,447,083$ \\
\hline Employment (Employees) & 11,127 & 48,208 & 175,511 & 281,599 & 268,549 \\
\hline \multicolumn{6}{|l|}{ Indirect Effect } \\
\hline Production (K EUR) & 258,903 & 612,250 & $2,270,199$ & $4,239,482$ & $4,136,517$ \\
\hline Added Value (K EUR) & 64,364 & 179,903 & 677,392 & $1,305,429$ & $1,368,611$ \\
\hline Employment (Employees) & 25,155 & 51,139 & 169,261 & 291,097 & 257,280 \\
\hline \multicolumn{6}{|l|}{ Total Effect } \\
\hline Production (K EUR) & 788,669 & $1,647,310$ & $5,918,811$ & $10,448,849$ & $9,694,268$ \\
\hline Added Value (K EUR) & 137,936 & 385,481 & $1,445,661$ & $2,739,569$ & $2,815,694$ \\
\hline Employment (Employees) & 35,989 & 96,491 & 339,535 & 562,931 & 513,427 \\
\hline PRO-MEMORIAM & 2010 & $2011-2020$ & 2021-2030 & $2031-2040$ & $2041-2050$ \\
\hline GDP Morocco (K EUR) & $76,694,200$ & $92,033,040$ & $110,439,648$ & $132,527,578$ & $159,033,093$ \\
\hline Total Effect (A.V.)/GDP & $0.18 \%$ & $0.42 \%$ & $1.31 \%$ & $2.07 \%$ & $1.77 \%$ \\
\hline Employment (Persons) & $10,551,306$ & $10,656,819$ & $10,763,387$ & $10,871,021$ & $10,979,731$ \\
\hline
\end{tabular}




\section{References}

1. De Arce, R.; Mahia, R.; Medina, E.; Escribano, G. A simulation of the economic impact of renewable energy development in Morocco. Energy Policy 2012, 46, 335-345. [CrossRef]

2. Mahia, R.; de Arce, R.; Medina, E. Assessing the Future of a CSP Industry in Morocco". Ramón Mahía, Rafael de Arce and Eva Medina. Energy Policy 2014, 69, 586-597. [CrossRef]

3. Simionescu, M.; Strielkowski, W.; Tvaronavičienè, M. Renewable Energy in Final Energy Consumption and Income in the EU-28 Countries. Energies 2020, 13, 2280. [CrossRef]

4. DESERTEC. Our Vision of the Union for the Mediterranean: The DESERTEC Concept. Deserts + Technology for Energy, Water and Climate Security, White Paper; The Club of Rome: Hamburg, Germany, 2008.

5. European Commission. Identification mission for the Mediterranean Solar Plan. In A Study Project Prepared in the Frame of European Neighbourhood and Partnership Instrument (ENPI)-Neighbourhood-Mediterranean E Eastern Europe, Implemented by Resources and Logistics; European Commission: Brussels, Belgium, 2010.

6. Adenle, A. Assessment of solar energy technologies in Africa-opportunities and challenges in meeting the 2030 agenda and sustainable development goal. Energy Policy 2020, 137, 111180. [CrossRef]

7. MENA. MENA Renewables Status Report. In Renewable Energy Policy Network for the 21st Century/UEA; Directorate of Energy, Climate Change and International Renewable Energy Agency: Paris, France, 2013.

8. Medina, E.; de Arce, R.; Mahia, R. Barriers to the investment in the Concentrated Solar Power sector in Morocco: A foresight approach using the Cross Impact Analysis for a large number of events. Futures 2015, 71, 36-56. [CrossRef]

9. Adenle, A.A.; Manning, D.T.; Arbiol, J. Mitigating climate change in Africa: Barriers to financing low-carbon development. World Dev. 2017, 100, 123-132. [CrossRef]

10. Jenniches, S. Assessing the regional economic impacts of renewable energy sources-A literature review. Renew. Sustain. Energy Rev. 2018, 93, 35-51. [CrossRef]

11. Dees, P.; Auktor, G. Renewable energy and economic growth in the MENA region: Empirical evidence and policy implications. Middle East Dev. J. 2018, 2, 225-247. [CrossRef]

12. Kiefer, C.P.; del Río, P. Analysing the barriers and drivers to concentrating solar power in the European Union. Policy implications. J. Clean. Prod. 2020, 251, 119400. [CrossRef]

13. Nakano, S.; Arai, S.; Washizu, A. Economic impacts of Japan's renewable energy sector and the feed-in tariff system: Using an input-output table to analyse a next-generation energy system. Environ. Econ. Policy Stud. 2017, 19, 555-580. [CrossRef]

14. Kost, C.; Engelkenb, M.; Schlegla, T. Value generation of future CSP projects in North Africa. Energy Policy 2012, 46, 88-99. [CrossRef]

15. Caldés, N.; Varela, M.; Santamaría, M.; Saéz, R. Economic impact of solar thermal electricity deployment in Spain. Energy Policy 2009, 37, 1628-1636. [CrossRef]

16. Algoso, D.; Rusch, E. Renewable Work: Job Growth from Renewable Energy Development in the Mid-Atlantic. NJPIRG Law and Policy Centery, 2004. Available online: www.ogel.org/article.asp?key=1233 (accessed on 10 July 2020).

17. Stoddard, L.; Abiecunas, J.; O'Connell, R. Economic, Energy, and Environmental Benefits of Concentrating Solar Power in California; Subcontract Report National Renewable Energy Laboratory NREL/SR-550-39291, operated for the U.S. Department of Energy Office of Energy Efficiency and Renewable Energy by Midwest Research Institute: Battelle, France, 2006.

18. Ciorba, U.; Pauli, F.; Menna, P. Technical and economic analysis of an induced demand in the photovoltaic sector. Energy Policy 2004, 32, 949-960. [CrossRef]

19. NREL (National Renewable Energy Laboratory). Assessment of Parabolic Through and Power Tower Solar Technology Cost and Performance Forecasts; Project prepared under Subcontract No. LAA-2-32458-01 by Sargent \& Lundy LLC Consulting Group; NREL (National Renewable Energy Laboratory): Chicago, IL, USA, 2003.

20. Antille, G.; Fontella, E.; Guillet, S. Changes in Technical Coefficients: The Experience with Swiss I/O Tables. In Proceedings of the Thirteen International Conference on Input-Output Techniques, Macerata, Italy, 21-25 August 2000.

21. Allen, R.I.G.; Gossling, W.F. Estimating and Projecting Input-Output Coefficients; Input-Output Publishing Co: London, UK, 1975. 
22. Dijkman, H.; Burgess, A. Estimating origin-destination matrices from incomplete data. Traffic Eng. Control 1994, 35, 563-565.

23. Komendantova, N.; Patt, A.; Williges, K. Solar power investment in North Africa: Reducing perceived risks. Renew. Sustain. Energy Rev. 2011, 15, 4829-4835. [CrossRef]

24. United Nations. World Investment Report 2008; United Nations Conference on Trade and Development: New York, NY, USA; Geneva, Switzerland, 2008.

25. FEM34-02. "Renewable Energies and Sustainable Development in the Mediterranean: Morocco and the Mediterranean Solar Plan (MSP)", étude FEMISE nFEM34-02 directed by Alejandro Lorca and Rafael de Arce. Available online: http://www.femise.org/PDF/ci2010/FEM34-02.pdf (accessed on 10 July 2020).

26. FEM35-05. The Impact of a Renewable Energies Cluster in Southern Countries: Viability and Economic Impact in Morocco. Etude FEMISE n ${ }^{\circ}$ FEM35-05, May 2014 directed by Rafael de Arce and Alejandro Lorca, May 2013. Available online: http://www.femise.org/en/2013/05/recherches/fem35-05-rex/ (accessed on 10 July 2020).

27. IEA. Technology Roadmap-Solar Photovoltaic Energy 2010, International Energy Agency, Paris. 2010. Available online: https://www.iea.org/reports/technology-roadmap-solar-photovoltaic-energy-2010 (accessed on 10 July 2020).

28. World Bank. "Morocco: Ouarzazate I Concentrated Solar Power Project SUMMARY OF DISCUSSION". Meeting of the Executive Directors, November 17th, 2011. Document number 65682, 2011. Available online: https://documents.worldbank.org/en/publication/documents-reports/documentdetail/ 939431468054559857/morocco-ouarzazate-concentrated-solar-power-project-summary-of-discussion (accessed on 10 July 2020).

29. Escribano, G.; Marin-Quesada, J.M.; San Martín, E. RES and risk: Renewable energy's contribution to energy security. A portfolio-based approach. J. Renew. Sustain. Rev. 2013, 26, 549-559. [CrossRef]

(C) 2020 by the authors. Licensee MDPI, Basel, Switzerland. This article is an open access article distributed under the terms and conditions of the Creative Commons Attribution (CC BY) license (http://creativecommons.org/licenses/by/4.0/). 